\title{
Labor Productivity In Emerging Markets: Evidence From Brazil, China, India, And Russia (BRIC)
}

Young-Hee Kang, Keimyung University, South Korea

Kyunga Na, Keimyung University, South Korea

Yang Sok Kim, Keimyung University, South Korea

\begin{abstract}
Despite the great amount of attention to emerging markets, much still remains unknown about firm performance in emerging economies. To fill this gap, this study aims to investigate factors that influence labor productivity of firms in Brazil, China, India, and Russia (BRIC countries). This study focuses on features of business environments of emerging markets such as informality, corruption, foreign ownership, and external audit. Using a cross-national sample of 8,885 firms from the World Bank Enterprise Surveys dataset, we find that informality is negatively associated with labor productivity, while corruption and external audit are positively related to labor productivity. Implications will be discussed.
\end{abstract}

Keywords: Labor Productivity; BRIC countries; Informality; Bribery; External Audit

\section{INTRODUCTION}

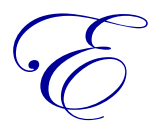

merging markets are very unstable and rapidly growing markets (Luo \& Park 2001; Puffer, McCarthy \& Boisot 2010). Since the early 2000s, emerging markets have played a critical role in the global economy (Holtbrügge \& Kreppel, 2012). Among the emerging markets, Brazil, Russia, India, and China (BRIC), have been considered as the fastest growing large economies (De Vries, Erumban, Timmer, Voskoboynikov \& Wu 2012; Djankov, Miguel, Qian, Roland \& Zhuravskaya, 2005). These countries have large potential for future contribution to the world economy because of the sizes of their population and economy (De Vries et al. 2012: 212). For instance, China and India have not only shown economic growth above the world average but also contributed to the world GDP growth during the past decade (De Vries et al. 2012). Brazil has been considered as a center of Latin American markets with the population of 626 million (United Nations, Department of Economic and Social Affairs 2015), and Russia has shown relatively rapid economic growth among the developing countries in Europe (Djankov et al. 2005).

As the importance of emerging markets has grown, the literature on BRIC has been enriched. However, the extant literature on these economies mainly focused on the characteristics of the business environment such as investment attractiveness (e.g., Alaimo, Fajnzylber, Guasch, Lopez \& Oviedo, 2009) and the institutional environment (e.g., Eunni \& Manolova, 2012). Such approaches, which are mainly based on country-level contexts, contribute to understanding the business environment of emerging economies. For instance, similar to other transition economies, BRIC is characterized by formal institutional voids - poor social overhead capital, ineffective legal systems, high levels of corruption, and so on - which in turn limit their transition into developed economies. However, it is unknown how such factors resulting from formal institutional voids affect firm-level performance in emerging markets such as BRIC. Therefore, it is necessary to determine what affects firm performance in BRIC. Yet, there is little empirical research that analyzes firm performance in BRIC.

Thus, this study aims to investigate the determinants of firm performance in BRIC countries. In particular, we examine which factors affect labor productivity in BRIC. As labor productivity refers to the efficiency of the workforce, much 
research uses it as an important indicator of firm performance (e.g., Chen, Hope, Li \& Wang, 2001; Kang \& Chung, 2015).

Drawing on the perspective of institutional voids, we focus on informality, firm bribery, external audit, and foreign ownership. In emerging economies, governments are more likely to have high levels of control over resources; administrative procedures for businesses are complex and time consuming; financial markets (including bank systems and stock markets) are under-developed; ownership is concentrated to a few shareholders, particularly owners and their families; and the level of monitoring of managerial decision is low. Because business environments can restrict firm decisions, these features of emerging markets can affect firm efficiency. Thus, we analyze how the abovementioned five organizational behaviors and characteristics influence labor productivity.

The current research makes several contributions to the existing literature. First, this study contributes to the literature on emerging markets by providing an understanding of firm performance in emerging markets. Using firm-level data, this study analyzes the factors that influence labor productivity of firms in BRIC. Second, this study will contribute to the literature on international business by providing indicators for comparing firm productivity among BRIC and presenting results based on these indicators. Although the four countries have common characteristics such as institutional voids, they also have some differences in their business environments. Therefore, it is necessary to identify which factor affects labor productivity in each country. In addition, by providing empirical evidence of determinants of labor productivity, this study has important practical implications for companies that are planning or considering moving into BRIC or other emerging markets. Likewise, the findings from this research may provide useful suggestions for policymakers, which contribute to improving labor productivity of emerging markets.

\section{PREVIOUS STUDIES AND THEORY DEVELOPMENT}

\subsection{Institutional Environment of Emerging Markets}

Emerging markets are defined as a very fast-growing and dynamic economy (Luo \& Park, 2001). Also, emerging economies are characterized by less-developed institutions or institutional voids (Kang \& Chung, 2015). The institutional environment, which consists of formal and informal norms, values, and rules (Eunni \& Manolova, 2012: 172), influences firm behaviors in doing business by limiting firms from obtaining resources for firm growth (DiMaggio \& Powell, 1983). Similar to other emerging markets, BRIC countries have certain common elements of institutional environments (Eunni \& Manolova, 2012): high levels of corruption and informality (e.g., Baik, Lee \& Lee, 2015) resulting in inefficiency of the government, poor corporate governance due to less-developed financial markets, low costs of workforce, high levels of uncertainty or risk (e.g., Fey \& Denison, 2003), and so on.

First, corruption is more salient in emerging markets, which in turn influences the efficiency of the economy (Aidt, 2009; Gill, Kharas \& Bhattasali, 2007). In addition, Spencer and Gomez (2011: 280) state that violation of or conformity to the corruption norm can influence firm performance in emerging markets where such norms have been institutionalized. $\mathrm{Wu}$ (2009: 75) states that corruption will have a negative effect on business costs by increasing the cost of production and the cost of financing. For example, in Asian emerging markets, corruption is likely to increase the business cost by $5 \%$ (Kraar, 1995).

Next, emerging markets are characterized by poor corporate governance, because they have less-developed financial regulations. In addition, in transitional economies, ownership is likely to be concentrated to a few controlling shareholders or family member. Concentrated ownership is likely to provide controlling shareholders with a motive to divert firm resources because there is information asymmetry between the outside shareholders and controlling shareholders (Morck, Yeung \& Yu, 2000; Claessens, Djankov, Fan \& Lang, 2002; Fan \& Wong, 2002). Family-run firms are more likely to be involved in bribery than others because they seek long-term management control (Wu, 2005). Moreover, poor accounting practices in emerging markets can have negative impacts on firm performance as they decrease the effort to reduce business costs such as bribery. Considering that the principles of good corporate governance tend to improve firm performance (Wu 2009), corporate governance can influence firm performance. 
From the perspective of institutional voids, we focus on informality, bribery, external audit, and foreign ownership because they are appropriate candidates that may affect firm performance in emerging markets, as we demonstrate below.

\subsection{Informality}

Informality plays a critical role in emerging economies, because such economies are likely to involve a great amount of unregistered businesses and employment in the informal sectors (Alaimo et al. 2009; Schneider \& Enste, 2000). There are different definitions of informality among scholars (e.g., Ruiz, Pérez, Bona \& Santana, 2009). In this study, informality is related to unregistered businesses that are less likely to be monitored by the regulatory authority because it is relevant to firm level performance. Precisely, informality is defined as competition with unregistered rivals.

High levels of informality mean that unregistered firms form a large part of an economy (Amin 2011; Gonzalez \& Lamanna, 2007). Djankov et al.'s (2005) findings imply that emerging markets tend to have larger informal economies because regulatory burdens are positively associated with firm entry costs (Levie \& Autio, 2011). Firms in the informal sector can benefit from low costs because they are less concerned with paying taxes and following regulations or laws (Baik et al. 2015). It would be likely that companies in the formal sector that compete with unregistered rivals are more likely to suffer from such disadvantages than their counterparts. This implies that having unregistered competitors should be negatively associated with organizational performance in emerging markets where regulatory burdens are relatively high. Moreover, some studies provide evidence that competition with firms in the informal sector has negative effects on firm performance (e.g., Kang \& Chung, 2015).

\subsection{Bribery}

The definition of corruption is categorized into two types: 1) bribes paid to government officials (LaPalombara, 1994; Luo 2005) and 2) exchanges between two private parties (Coase 1979). However, as the majority of firm bribes are paid to government officials (Luo 2005), this study focuses on bribery to public officials, as such bribery is a common type of corruption that deteriorates management quality (Lee \& Weng, 2013).

Some factors that influence firm bribery are the level of the economic development (Husted 1999), cultures (Husted, 1999; Martin, Cullen \& Johnson, 2007), and top-management characteristics (Collins, Uhlenbruck \& Rodriguez, 2009). For example, as corruption is common in countries where the government has monopoly over resources (Alam, 1995), bribes have been regarded more common in emerging markets or transition economies where the gross domestic product (GDP) is low and legal systems are less developed (Husted 1999; Rodriguez, Uhlenbruck \& Eden 2005; Sanchez, Gomez \& Wated, 2008). Husted (1999) also states that economic development is negatively associated with corruption and that inequality in income distribution is more likely to have a negative effect on corruption.

In addition, cultural values affect the level of corruption (Husted, 1999; Martin et al. 2007). In particular, power distance (Husted 1999), masculinity (Davis \& Ruhe, 2003; Husted, 1999), and uncertainty avoidance (Husted 1999) are positively related to corruption. Compared with developed economies, BRIC is characterized by higher levels of power distance, masculinity, and uncertainty avoidance (Eunni \& Manolova, 2012). Moreover, Research on corruption uses the Bribe Payers index (BPI) ${ }^{1}$ reported by Transparency International (2011) as an indicator of the extent to which a certain country is corrupt (e.g., Spencer \& Gomez, 2011). The BPI ranks Brazil, India, China, and Russia as $14^{\text {th }}$, $19^{\text {th }}, 27^{\text {th }}$, and $28^{\text {th }}$, respectively. Much research has provided strong support for the negative effect of corruption on economic development (Lambsdorff, 2003; Wei, 2000); however, there is little empirical support for effects of corruption on firm performance in emerging markets (e.g., Lambsdorff, 2003). Therefore, it is necessary to examine the extent to which bribery affects labor productivity in BRIC.

\subsection{External Audit}

The agency theory suggests that inside controllers are more motivated to provide information favorable to themselves to outsiders. Conducting external audits is likely to reduce information asymmetries between corporate insiders and

${ }^{1}$ The index ranks 28 countries depending on the perceived likelihood of firm bribery abroad. 
outside shareholders by increasing the credibility of financial records (Dopuch \& Simunic, 1982). Considering that high control concentration is likely to increase agency problems (González \& García-Meca, 2014), external auditors can play an important role in mitigating the agency problems. Companies audited externally are less likely to engage in unlawful behaviors such as earning management (Chen et al. 2011). In order to mitigate the agency problem, an external audit may be a reasonable choice for firms in emerging markets where the concentration of ownership is high, because external independent audits play a role in monitoring managerial decisions (Fan \& Wong, 2005).

Moreover, external audit is expected to lead to improvement in labor productivity in emerging markets by enhancing transparency in business operation (Samudhram, Stewart, Wickramanayake \& Sinnakkannu, 2014). When employees observe that their leaders engage in unethical behaviors, their trust in managers is likely to decrease, while their organizational cynicism tends to increase (Johnson \& O'Leary-Kelly, 2003). Such negative attitudes of employees toward their employing organizations have negative effects on their job performance (Johnson \& O'Leary-Kelly, 2003). This implies that employees may have positive attitudes toward their job when they perceive the integrity of their employing organizations. Considering this, an external audit may be positively associated with labor productivity. Moreover, institutions wherein ownership is concentrated to one or a few controlling owners are less likely to have motives to employ a high-quality auditor (Fan \& Wong, 2005: 42). Therefore, employees are more likely to perceive integrity when a company is externally audited, which in turn may contribute to labor productivity in emerging markets.

\subsection{Foreign Ownership}

Ownership structure has remarkable effects on management decisions such as firm strategies, resource allocation, and so on (Brouthers \& Hennart, 2007). Monitoring power also comes from ownership structure, and monitoring management decisions result from ownership structure (González \& García-Meca, 2014). Previous literature on the ownership structure of emerging markets has paid attention to insider (internal) ownership, ownership concentration, and family ownership (e.g., González \& García-Meca, 2014) because 1) firms are likely to be owned by family members; 2) the proportion of ownership held by major shareholders is large; and 3) majority shareholders participate in the management.

In emerging markets, however, foreign ownership can also play a critical role in firm performance. In general, as foreign investors are less likely to be connected to controlling shareholders such as top management, they have more incentives to monitor managerial decisions efficiently (Chen, Chiou, Chou \& Syue, 2009). Some studies found that foreign ownership has positive effects on organizational performance in transitional economies such as Brazil (e.g., Beck, Crivelli \& Summerhill, 2005; Crystal, Dages \& Goldberg, 2001), India (e.g., Chhibber \& Majumdar, 1999; Khanna \& Palepu 1999), and China (e.g., Buckley, Wang \& Clegg 2007; Greenaway, Guariglia \& Yu, 2014) by using appropriate monitoring skills. Further, some studies report that foreign investors contribute to improvement in firm performance, such as labor productivity and profitability, in transition economies (e.g., Claessens \& Djankov, 1999).

To our knowledge, little empirical research has been conducted on identifying factors that influence labor productivity in BRIC. Thus, this study aims to investigate how much informal competition, external audit, bribery, and foreign ownership affect labor productivity of firms in BRIC.

\section{METHOD}

\subsection{Sample: World Bank Enterprise Surveys}

The current study uses the World Bank Enterprise Surveys (WBES) data ${ }^{2}$ in order to analyze the effects of test variables on labor productivity. Interviewing business owners or top managers with standard survey instruments, World Bank has collected firm-level information that includes a variety of business issues such as firm characteristics, corruption, performance measures, and so on. The country data are comparable because WBES employs standardized questionnaires. Therefore, this study can benefit by incorporating WBES data of the four BRIC countries.

\footnotetext{
${ }^{2}$ Further information on the WBES data can be downloaded from http://www.enterprisesurveys.org.
} 
We developed a cross-country sample of 8,885 firms from the WBES dataset in order to analyze the extent to which the test variables influence labor productivity. We excluded observations with incomplete information for the test variables of this study such as corruption, informal competition, and so on. The WBES are conducted for 15-20 countries per year, which are updated around every three to five years. We used the most recent wave of the WBES: Surveys conducted in Brazil in 2009, China in 2009, Russia in 2012, and India in 2014. Table 1 presents the characteristics of the sample. There are 6,125 (68.9\%) manufacturing, 1,343 (15.1\%) wholesale and retail, 1,024 $(11.5 \%)$ service, and $393(4.4 \%)$ construction firms. The average firm age is 15.7 years $(S D=13.3)$; the average number of employees is 133.04 ( $S D=626.56) ; 6 \%$ are exporters; $37.43 \%$ of firms have between 21 to 99 employees; and $139(1.56 \%)$ are listed on the stock exchange. With regard to the country, Brazil, Russia, India, and China comprise $5 \%, 25 \%, 60 \%$, and $10 \%$ of the overall sample, respectively.

Table 1. Characteristics of the Sample

\begin{tabular}{|c|c|c|c|c|c|c|}
\hline \multicolumn{2}{|r|}{ Category } & BRIC & Brazil & Russia & India & China \\
\hline \multirow{4}{*}{ Industry } & Wholesale \& retail (\%) & $\begin{array}{c}1,343 \\
(15.12 \%)\end{array}$ & $\begin{array}{c}24 \\
(4.71 \%)\end{array}$ & $\begin{array}{c}914 \\
(41.23 \%)\end{array}$ & $\begin{array}{c}313 \\
(5.91 \%)\end{array}$ & $\begin{array}{c}92 \\
(10.62 \%)\end{array}$ \\
\hline & Construction (\%) & $\begin{array}{c}393 \\
(4.42 \%)\end{array}$ & $\begin{array}{c}3 \\
(0.59 \%)\end{array}$ & $\begin{array}{c}209 \\
(9.43 \%)\end{array}$ & $\begin{array}{c}148 \\
(2.80 \%)\end{array}$ & $\begin{array}{c}33 \\
(3.81 \%)\end{array}$ \\
\hline & Service $(\%)$ & $\begin{array}{c}1,024 \\
(11.53 \%)\end{array}$ & $\begin{array}{c}48 \\
(9.41 \%)\end{array}$ & $\begin{array}{c}247 \\
(11.14 \%)\end{array}$ & $\begin{array}{c}573 \\
(10.83 \%)\end{array}$ & $\begin{array}{c}156 \\
(18.01 \%)\end{array}$ \\
\hline & Manufacturing \& other (\%) & $\begin{array}{c}6,125 \\
(68.94 \%)\end{array}$ & $\begin{array}{c}435 \\
(85.29)\end{array}$ & $\begin{array}{c}847 \\
(38.20 \%)\end{array}$ & $\begin{array}{c}4,258 \\
(80.46 \%)\end{array}$ & $\begin{array}{c}585 \\
(67.55 \%)\end{array}$ \\
\hline \multicolumn{2}{|c|}{ Ave. Firm age (yrs.) } & $\begin{array}{c}15.69 \\
(S D=13.32)\end{array}$ & 19.89 & 10.19 & 18.28 & 11.47 \\
\hline \multicolumn{2}{|c|}{ Ave. Firm size (employees) } & $\begin{array}{c}133.04 \\
(S D=626.56)\end{array}$ & 79.43 & 121.69 & 147.12 & 107.69 \\
\hline \multicolumn{2}{|c|}{$\begin{array}{l}\text { Firm size: Small } \\
(\text { employees } \leq 99, \%)\end{array}$} & $\begin{array}{c}3,326 \\
(37.43 \%)\end{array}$ & $\begin{array}{c}242 \\
(47.45 \%)\end{array}$ & $\begin{array}{c}655 \\
(29.54 \%)\end{array}$ & $\begin{array}{c}2,121 \\
(40.08 \%)\end{array}$ & $\begin{array}{c}308 \\
(35.57 \%)\end{array}$ \\
\hline \multicolumn{2}{|c|}{$\begin{array}{l}\text { Firm size: Medium or Large (100+ } \\
\text { employees, \%) }\end{array}$} & $\begin{array}{c}3,413 \\
(38.41 \%)\end{array}$ & $\begin{array}{c}167 \\
(32.75 \%)\end{array}$ & $\begin{array}{c}979 \\
(44.16 \%)\end{array}$ & $\begin{array}{c}1,892 \\
(35.75 \%)\end{array}$ & $\begin{array}{c}375 \\
(43.30 \%)\end{array}$ \\
\hline \multicolumn{2}{|c|}{ Subsidiary of large firms (\%) } & $\begin{array}{c}1,591 \\
(17.91 \%)\end{array}$ & $\begin{array}{c}107 \\
(20.98 \%)\end{array}$ & $\begin{array}{c}164 \\
(7.40 \%)\end{array}$ & $\begin{array}{c}1,198 \\
(22.64 \%)\end{array}$ & $\begin{array}{c}122 \\
(14.09 \%)\end{array}$ \\
\hline \multicolumn{2}{|c|}{$\begin{array}{l}\text { Market type } \\
\text { (domestic market, \%) }\end{array}$} & $\begin{array}{c}8359 \\
(94.08 \%)\end{array}$ & $\begin{array}{c}485 \\
(95.10 \%)\end{array}$ & $\begin{array}{c}2059 \\
(92.87 \%)\end{array}$ & $\begin{array}{c}5003 \\
(94.54 \%)\end{array}$ & $\begin{array}{c}812 \\
(93.76 \%)\end{array}$ \\
\hline \multicolumn{2}{|c|}{ Listed on s stock exchange (\%) } & $139(1.56 \%)$ & $13(2.55 \%)$ & $0(0 \%)$ & $99(1.87 \%)$ & $27(3.12 \%)$ \\
\hline
\end{tabular}

\subsection{Estimations (Labor productivity equations)}

In order to analyze the effects of the explanatory variables on labor productivity, we used an ordinary least squares (OLS) model by including alternatives that may affect the outcome variable. We estimated a simple linear regression for labor productivity as follows:

$$
\left.y_{i}=\alpha+\beta_{i} \text { (Test variables }\right)+\gamma_{i} \text { Controls }+\varepsilon_{i},
$$

where $y_{i}$ refers to labor productivity (sales per employee, in logs); Test variables refers to the labor productivity determinants (informality, bribery, external audit, and foreign ownership) discussed in Section 2, Controls refers to control variables, and $\varepsilon$ is a random error term. Several control variables are included in the model to control for their possible effects on labor productivity. More specifically, we consider firm age, firm size, subsidiary status, export sales (\%), external financing (\%), listing status, tax inspection, market type, and dummies for industry and country in the regression model for the total sample. Dummies for country are excluded in the regression model for each country. To control for firm age and firm size, we use the natural logarithm transformation of firm age and firm size dummies (small size: $1=$ less than 21 employees, $0=$ otherwise; medium size: $1=21 \leq$ employees $\leq 99$, and $0=$ otherwise; large size as a base). Moreover, a firm's subsidiary status $(1=$ part of a large firm, $0=$ otherwise $)$, listing status $(1=$ listed firms, $0=$ unlisted ones), tax inspection $(1=$ firms having a tax inspection, $0=$ otherwise $)$, and market type $(1$ $=$ the main market of the firm is domestic, $0=$ otherwise) are controlled using dummy variables. To mitigate the effects 
of the size of export sales and external financing, we include the percentages of external sales and external financing as control variables, respectively. Finally, in order to control for industry and country effects, dummies for industry (dummies for wholesale and retail, construction, and service industries; manufacturing and other industries as a base) and country (dummies for Russia, India, and China; Brazil as a base) are considered. Based on the model variables discussed above, we construct the ordinary least square regression model for the total sample as follows:

$$
\begin{aligned}
& \text { Labor productivity }=a+\beta_{1} \text { Informality }+\beta_{2} \text { Bribery }+\beta_{3} \text { External audit } \\
& +\beta_{4} \text { Foreign ownership }+\gamma_{1} \text { Firm age }+\gamma_{2} \text { Small size }+\gamma_{3} \text { Medium size }+\gamma_{4} \text { Subsidiary status } \\
& +\gamma_{5} \text { Export sales }+\gamma_{6} \text { External financing }+\gamma_{7} \text { Listing status }+\gamma_{8} \text { Tax inspection } \\
& +\gamma_{9} \text { Market type }+\gamma_{10} \text { Wholesale \& retail industry }+\gamma_{11} \text { Construction industry } \\
& +\gamma_{12} \text { Service industry }+\gamma_{13} \text { Russia }+\gamma_{14} \text { India }+\gamma_{15} \text { China }
\end{aligned}
$$

\section{RESULTS}

Table 2 reports the descriptive statistics and Pearson correlations of the model variables, while Table 3 presents the ordinary least squares regression analysis results of both the total sample and individual country samples. Positive coefficient estimates indicate the positive effects of the corresponding explanatory variables on labor productivity,

\begin{tabular}{|c|c|c|c|c|c|c|c|c|c|}
\hline No. & Variable & Mean & $S D$ & 1 & 2 & 3 & 4 & 5 & 6 \\
\hline 1. & Labor productivity & 10.07 & 1.89 & 1.00 & & & & & \\
\hline 2. & Informality & 0.40 & 0.49 & $-0.11^{* * *}$ & 1.00 & & & & \\
\hline 3. & Bribery & 0.33 & 0.47 & $0.09^{* * *}$ & $-0.10^{* * *}$ & 1.00 & & & \\
\hline 4. & External audit & 2.55 & 0.63 & $0.18^{* * *}$ & $-0.03^{* *}$ & $0.24^{* * *}$ & 1.00 & & \\
\hline 5. & Foreign ownership & 0.01 & 0.10 & $0.07^{* * *}$ & -0.01 & 0.00 & 0.01 & 1.00 & \\
\hline 6 & Firm age & 2.55 & 0.73 & $0.13^{* * *}$ & $-0.09^{* * *}$ & $0.34^{* * *}$ & -0.01 & $-0.24^{* * *}$ & 1.00 \\
\hline 7. & Small size & 0.37 & 0.48 & 0.01 & -0.01 & $0.10^{* * *}$ & -0.01 & $-0.12^{* * *}$ & $0.27^{* * *}$ \\
\hline 8. & Medium size & 0.38 & 0.49 & $-0.02 \dagger$ & 0.01 & 0.00 & 0.00 & $0.04^{* * *}$ & $-0.04^{* * *}$ \\
\hline 9. & Subsidiary status & 0.18 & 0.38 & -0.01 & $0.04^{* * *}$ & 0.01 & $0.05^{* * *}$ & $-0.05^{* * *}$ & $0.05^{* * *}$ \\
\hline 10. & Export sales & 0.07 & 0.21 & $0.05^{* * *}$ & 0.01 & $-0.05^{* * *}$ & -0.01 & $0.09^{* * *}$ & $-0.13^{* * *}$ \\
\hline 11. & External financing & 0.31 & 0.34 & 0.00 & $0.06^{* * *}$ & $-0.05^{* * *}$ & 0.01 & $0.12^{* * *}$ & $-0.15^{* * *}$ \\
\hline 12. & Listing status & 0.02 & 0.12 & 0.00 & 0.01 & $0.03^{* *}$ & $0.04^{* *}$ & $-0.02^{*}$ & $0.07^{* * *}$ \\
\hline 13. & Tax inspection & 0.55 & 0.50 & $-0.04^{* * *}$ & 0.00 & $--0.04^{* * *}$ & 0.00 & $0.25^{* * *}$ & $-0.04^{* * *}$ \\
\hline 14. & Market type & 0.94 & 0.24 & $-0.08^{* * *}$ & 0.01 & $0.04^{* * *}$ & 0.01 & $-0.10^{* * *}$ & $0.10^{* * *}$ \\
\hline 15. & Wholesale \& retail & 0.15 & 0.36 & 0.02 & $0.02^{*}$ & $-0.04^{* * *}$ & 0.01 & $0.06^{* * *}$ & $-0.15^{* * *}$ \\
\hline 16. & Construction & 0.04 & 0.21 & -0.02 & 0.01 & $-0.03^{* *}$ & -0.02 & $0.04^{* * *}$ & $-0.08^{* * *}$ \\
\hline 17. & Service & 0.12 & 0.32 & 0.01 & 0.02 & 0.00 & 0.00 & 0.01 & $-0.03^{* *}$ \\
\hline 18. & Russia & 0.25 & 0.43 & 0.01 & $0.03^{* *}$ & 0.01 & $0.04^{* * *}$ & $0.12^{* * *}$ & $-0.29^{* * *}$ \\
\hline 19. & India & 0.60 & 0.49 & $-0.35^{* * *}$ & -0.01 & $-0.17^{* * *}$ & $-0.11^{* * *}$ & $-0.09^{* * *}$ & $0.25^{* * *}$ \\
\hline 20. & China & 0.10 & 0.30 & $0.24^{* * *}$ & -0.01 & $0.14^{* * *}$ & $0.05^{* * *}$ & $0.03^{*}$ & $-0.06^{* * *}$ \\
\hline
\end{tabular}
while negative ones indicate the negative effects. As seen in Table 2, the correlations among test variables are not high, and the variance inflation factors of the variables are less than five, implying that our study may not have a serious multicollinearity problem.

Table 2. Descriptive Statistics and Correlations

(Table 2 continued on next page) 
(Table 2 continued)

\begin{tabular}{|c|c|c|c|c|c|c|c|c|}
\hline No. & Variable & 7 & 8 & 9 & 10 & 11 & 12 & 13 \\
\hline 7. & Small size & 1.00 & & & & & & \\
\hline 8. & Medium size & $-0.61^{* * *}$ & 1.00 & & & & & \\
\hline 9. & Subsidiary status & 0.01 & 0.00 & 1.00 & & & & \\
\hline 10. & Export sales & $-0.18^{* * *}$ & -0.01 & 0.00 & 1.00 & & & \\
\hline 11. & External financing & -0.01 & $0.03^{* *}$ & $0.04^{* * *}$ & $0.03^{* *}$ & 1.00 & & \\
\hline 12. & Listing status & -0.01 & 0.00 & $0.13^{* * *}$ & -0.01 & -0.01 & 1.00 & \\
\hline 13. & Tax inspection & $-0.03^{* *}$ & 0.00 & $-0.07^{* * *}$ & 0.01 & $0.06^{* * *}$ & -0.01 & 1.00 \\
\hline 14. & Market type & $0.13^{* * *}$ & 0.01 & -0.01 & $-0.70^{* * *}$ & $-0.03^{* *}$ & 0.00 & 0.00 \\
\hline 15. & Wholesale \& retail & $-0.05^{* * *}$ & $0.04^{* * *}$ & $-0.04^{* * *}$ & 0.01 & 0.00 & $-0.02 \dagger$ & -0.01 \\
\hline 16. & Construction & $-0.02^{*}$ & 0.01 & -0.02 & 0.00 & 0.01 & -0.01 & -0.01 \\
\hline 17. & Service & -0.01 & -0.01 & 0.01 & 0.01 & 0.00 & $0.02 \dagger$ & -0.01 \\
\hline 18. & Russia & $-0.09^{* * *}$ & $0.07^{* * *}$ & $-0.16^{* * *}$ & 0.01 & $0.05^{* * *}$ & -0.02 & $-0.07^{* * *}$ \\
\hline 19. & India & $0.07^{* * *}$ & $-0.07^{* * *}$ & $0.15^{* * *}$ & -0.01 & $-0.04^{* * *}$ & $0.04^{* * *}$ & $0.03^{* *}$ \\
\hline 20. & China & -0.01 & $0.03^{* *}$ & $-0.03^{* *}$ & 0.01 & 0.01 & -0.02 & $0.04^{* * *}$ \\
\hline
\end{tabular}

\begin{tabular}{|c|c|c|c|c|c|c|c|c|}
\hline No. & Variable & 14 & 15 & 16 & 17 & 18 & 19 & 20 \\
\hline 14. & Market type & 1.00 & & & & & & \\
\hline 15. & Wholesale \& retail & $-0.03^{* *}$ & 1.00 & & & & & \\
\hline 16. & Construction & -0.01 & $-0.09^{* * *}$ & 1.00 & & & & \\
\hline 17. & Service & $-0.02 \dagger$ & $-0.15^{* * *}$ & $-0.08^{* * *}$ & 1.00 & & & \\
\hline 18. & Russia & $-0.03^{* *}$ & $0.42^{* * *}$ & $0.14^{* * *}$ & -0.01 & 1.00 & & \\
\hline 19. & India & $0.02^{*}$ & $-0.31^{* * *}$ & $-0.10^{* * *}$ & $-0.03^{* *}$ & $-0.70^{* * *}$ & 1.00 & \\
\hline 20. & China & 0.00 & $-0.04^{* * *}$ & -0.01 & $0.07^{* * *}$ & $-0.19^{* * *}$ & $-0.40^{* * *}$ & 1.00 \\
\hline
\end{tabular}

Notes. $N=8,885$.

$\dagger p<.10 ; * p<.05 ; * * p<.01 ; * * * p<.001$.

Table 3 provides results for when the regression is performed over each sample. First, the regression results based on the total sample are reported in the column of BRIC. Variable informality is negatively related to labor productivity $(\beta=-0.30, p<.001)$, indicating that higher number of informal competitors lead to lower labor productivity. On the other hand, bribery is positively associated with labor productivity $(\beta=0.31, p<.001)$, which indicates that greater corruption leads to greater labor productivity. Similar to bribery, external audit has strong positive effects on labor productivity $(\beta=0.79, p<.001)$. This suggests that firms that have an external audit are more likely to have relatively higher levels of labor productivity compared with their counterparts. The regression results based on each country are shown in the column for the corresponding country. Except Brazil, the other three countries have a similar pattern of relations between the test variables and labor productivity. Specifically, compared with other explanatory variables, the external audit has relatively large effects on productivity in all four countries; Brazil, $\beta=0.44, p<.001$; Russia, $\beta$ $=1.07, p<.001$; India, $\beta=0.66, p<.001$; and China, $\beta=1.0, p<.001$. In addition, informality has significant negative effects on labor productivity in Russia $(\beta=-0.41, p<.001)$, India $(\beta=-0.26, p<.001)$, and China $(\beta=-0.38, p<$ $.001)$, while it is not significant for Brazil $(\beta=-0.06, n s)$. For Brazil, bribery has the largest effect on labor productivity. Interestingly, with respect to bribery, informality has significant positive effects on productivity in Russia $(\beta=0.43, p<.001)$ and India $(\beta=0.27, p<.001)$, while it is negatively related to productivity in Brazil $(\beta=$ $-0.63, p<.01)$. Finally, bribery is insignificant in China $(\beta=-0.04, n s)$. 
Table 3. Regression result for Labor Productivity (OLS)

\begin{tabular}{|c|c|c|c|c|c|}
\hline Variable & $\begin{array}{c}\text { BRIC } \\
(N=\mathbf{8 , 8 8 5})\end{array}$ & $\begin{array}{c}\text { Brazil } \\
(N=\mathbf{5 1 0})\end{array}$ & $\begin{array}{c}\text { Russia } \\
(N=\mathbf{2 , 2 1 7})\end{array}$ & $\begin{array}{c}\text { India } \\
(N=\mathbf{5 , 2 9 2})\end{array}$ & $\begin{array}{c}\text { China } \\
(N=866)\end{array}$ \\
\hline Intercept & $12.04^{* * * *}$ & $10.95^{* * *}$ & $9.84^{* * *}$ & $8.32^{* * *}$ & $8.32^{* * *}$ \\
\hline \multicolumn{6}{|l|}{ Independent variables } \\
\hline Informality & $-0.30^{* * *}$ & 0.06 & $-0.41^{* * *}$ & $-0.26^{* * *}$ & $-0.38^{* * *}$ \\
\hline Bribery & $0.31^{* * *}$ & $-0.63^{* * *}$ & $0.43^{* * *}$ & $0.27^{* * *}$ & -0.04 \\
\hline External audit & $0.79^{* * *}$ & $0.44^{* * *}$ & $1.07^{* * *}$ & $0.66^{* * *}$ & $1.00^{* * *}$ \\
\hline Foreign ownership & -0.03 & -0.17 & 0.03 & 0.15 & -0.39 \\
\hline \multicolumn{6}{|l|}{ Control Variables } \\
\hline Firm age & $0.45^{* * *}$ & $1.04^{* * *}$ & $0.12^{*}$ & $0.51^{* * *}$ & $1.33^{* * *}$ \\
\hline \multicolumn{6}{|c|}{ Firm size dummy (Large) } \\
\hline Small size & $-0.24^{* * *}$ & -0.02 & $-0.38^{* * *}$ & $-0.22^{* * *}$ & -0.22 \\
\hline Medium size & $-0.24^{* * *}$ & -0.16 & $-0.23^{*}$ & $-0.24^{* * *}$ & $-0.31^{*}$ \\
\hline Subsidiary status & $0.08 \dagger$ & -0.05 & 0.04 & 0.06 & $0.38^{*}$ \\
\hline Export sales & 0.07 & 0.49 & -0.10 & 0.11 & 0.31 \\
\hline External Financing & 0.08 & $0.32 \dagger$ & 0.06 & $0.13^{*}$ & -0.10 \\
\hline Listing status & $-0.25 \dagger$ & $-0.70^{*}$ & 0.00 & $-0.36^{*}$ & 0.10 \\
\hline Tax Inspection & $-0.24^{* * *}$ & -0.08 & $-0.45^{* * *}$ & $-0.20^{* * *}$ & $-0.30^{* *}$ \\
\hline Market type & $-0.50^{* * *}$ & -0.18 & $-0.65^{* *}$ & $-0.42^{* * *}$ & -0.30 \\
\hline \multicolumn{6}{|c|}{$\begin{array}{l}\text { Industry dummy } \\
\text { (Manufacturing \& other) }\end{array}$} \\
\hline Wholesale \& retail & 0.05 & -0.29 & 0.07 & 0.10 & 0.15 \\
\hline Construction & -0.06 & 0.32 & -0.01 & -0.18 & 0.34 \\
\hline Service & 0.02 & -0.17 & 0.04 & 0.02 & 0.14 \\
\hline \multicolumn{6}{|c|}{ Country Dummy (Brazil) } \\
\hline Russia & $-2.82^{* * *}$ & - & - & - & - \\
\hline India & $-3.56^{* * *}$ & - & - & - & - \\
\hline China & $-1.50^{* * *}$ & - & - & - & - \\
\hline Adjusted $\mathrm{R}^{2}$ & $32.98 \%$ & $12.76 \%$ & $10.58 \%$ & $10.10 \%$ & $23.45 \%$ \\
\hline$F$ Value & $219.57^{* * *}$ & $5.38^{* * *}$ & $17.38^{* * *}$ & $35.98^{* * *}$ & $16.59^{* * *}$ \\
\hline
\end{tabular}

Notes: Standardized beta $(\beta)$ reported.

$\dagger p<.10 ;^{*} p<.05 ; * * p<.01 ; * * * p<.001$.

In order to obtain robustness, we conduct additional analyses using a step-wise variable selection process (Hult et al. 2008). In the first step, we perform the regression with all independent variables. Based on the results, we filter the variables and use only the most relevant variables in a second regression (He, Zhang \& Wang, 2015). Table 4 summarizes the sensitivity test results. While there is little increase in Adjusted $R^{2}$ between the original equations and the corrected equations, $F$ values of the corrected equations are greater than those of the original equations. In general, the sensitivity test results are similar to the main results in Table 4 , suggesting that the corrected equations provide further support for the results of this study. 
Table 4. Sensitivity Test Result (using stepwise variable selection)

\begin{tabular}{|c|c|c|c|c|c|}
\hline Variable & $\begin{array}{c}\text { BRIC } \\
(N=\mathbf{8 , 8 8 5})\end{array}$ & $\begin{array}{c}\text { Brazil } \\
(N=\mathbf{5 1 0})\end{array}$ & $\begin{array}{c}\text { Russia } \\
(N=\mathbf{2 , 2 1 7})\end{array}$ & $\begin{array}{c}\text { India } \\
(N=5,292)\end{array}$ & $\begin{array}{c}\text { China } \\
(N=866)\end{array}$ \\
\hline Intercept & $12.19^{* * *}$ & $11.04^{* * *}$ & $9.85^{* * *}$ & $8.45^{* * *}$ & $8.56^{* * *}$ \\
\hline \multicolumn{6}{|l|}{ Independent variables } \\
\hline Informality & $-.30^{* * *}$ & - & $-.40^{* * *}$ & $-.25^{* * *}$ & $-.38^{* * *}$ \\
\hline Bribery & $.31^{* * *}$ & $-.58^{* *}$ & $.43^{* * *}$ & $.27^{* * *}$ & - \\
\hline External audit & $.79^{* * *}$ & $.42^{* * *}$ & $1.06^{* * *}$ & $.66^{* * *}$ & $1.00^{* * * *}$ \\
\hline Foreign ownership & - & - & - & - & - \\
\hline \multicolumn{6}{|l|}{ Control Variables } \\
\hline Firm age & $.46^{* * *}$ & $.97^{* * *}$ & $.12^{*}$ & $.52^{* * *}$ & $1.31^{* * *}$ \\
\hline \multicolumn{6}{|c|}{ Firm size dummy (Large) } \\
\hline Small size & $-.24^{* * *}$ & - & $-.38^{* * *}$ & $-.23^{* * *}$ & $-.25 \dagger$ \\
\hline Medium size & $-.23^{* * *}$ & - & $-.23^{*}$ & $-.24^{* * *}$ & $-.34^{*}$ \\
\hline Subsidiary status & $.08 \dagger$ & - & - & - & $.39^{* *}$ \\
\hline Export sales & & - & - & - & - \\
\hline External Financing & & $.30 \dagger$ & - & $.13^{*}$ & - \\
\hline Listing status & $-.25 \dagger$ & $-.63 \dagger$ & & $-.33^{*}$ & \\
\hline Tax Inspection & $-.24^{* * *}$ & & $-.45^{* * *}$ & $-.20^{* * *}$ & $-.31^{* *}$ \\
\hline Market type & $-.54^{* * *}$ & $-.60^{*}$ & $-.60^{* * *}$ & $-.49^{* * *}$ & $-.50^{*}$ \\
\hline \multicolumn{6}{|c|}{$\begin{array}{l}\text { Industry dummy } \\
\text { (Manufacturing \& other) }\end{array}$} \\
\hline Wholesale \& retail & - & - & - & - & - \\
\hline Construction & - & - & - & - & - \\
\hline Service & - & - & - & - & - \\
\hline \multicolumn{6}{|c|}{ Country Dummy (Brazil) } \\
\hline Russia & $-2.81^{* * *}$ & - & - & - & - \\
\hline India & $-3.57^{* * *}$ & - & - & - & - \\
\hline China & $-1.50^{* * *}$ & - & - & - & - \\
\hline Adjusted $\mathrm{R}^{2}$ & $32.99 \%$ & $13.17 \%$ & $10.79 \%$ & $10.12 \%$ & $23.73 \%$ \\
\hline F Value & $337.39^{* * *}$ & $13.87^{* * *}$ & $30.80^{* * *}$ & $60.58^{* * *}$ & $34.64^{* * *}$ \\
\hline
\end{tabular}

Notes: Standardized beta $(\beta)$ reported.

$\dagger p<.10 ; * p<.05 ; * * p<.01 ; * * * p<.001$.

\section{DISCUSSION}

This study aims to examine the factors that may influence the firm productivity of emerging markets using the WBES dataset. We find that informality, bribery, and external audit can influence labor productivity. Specifically, competitions with unregistered rivals have negative effects on labor productivity, while external audit and bribery are positively related to labor productivity. On the other hand, foreign ownership has insignificant impacts on labor productivity in BRIC countries. It may be because the portion of foreign ownership is quite low $(M=0.01, S D=0.10)$, which may lead to slight or insignificant effects on labor productivity.

This study contributes to the literature on internal management by identifying factors such as informality, external audit, etc., which might influence the labor productivity of emerging markets such as BRIC countries. The question of what business practices contribute to increases in firm performance of emerging markets has drawn attention form international business researchers. The findings of this study may provide answers to these types of questions by using empirical evidence of firm-level performance. Also, the findings contribute to the research on emerging markets by explaining how business practices or behaviors that result from the institutional features of emerging markets - such as high levels of informality and bribery — affect firm performance.

In addition, the findings of this study will have practical implications for practitioners and policymakers of emerging markets. First, the findings imply that the regulatory framework plays a critical role in firm performance in emerging markets. In particular, external audit is the most important determinant of firm labor productivity. This implies that significant growth or increase in firm performance can be limited by the investment climate. Firm competitiveness or 
growth is influenced by compliance to regulation. Likewise, informal competition is negatively associated with labor productivity and firm performance, which means that the government needs to reduce the level of informality or the ratio of the informal sectors to the national economy.

Moreover, this study contributes to the understanding of firm productivity of emerging markets, which is an important area of interest to MNEs. The results of this study suggest several conditions that can contribute to improving the firm performance of both BRIC as a whole and each country separately. For example, in cases of India and Russia, bribery affects productivity positively, but it is negatively related to productivity in Brazil.

Despite of these contributions, this study has some limitations, which will provide suggestions for future research. The main limitation is that this study uses the dataset from different years: Brazil from 2009, China from 2009, Russia from 2012, and India from 2014. This means that the enterprise survey in Brazil and China was conducted just after the global financial crisis of 2008, while the survey in Russia and India was conducted a few years after the immediate impact of the crisis. As the WBES questionnaires are standardized, there is no difference in the measures used in this study. However, the local economic conditions of BRIC as well as the global economy were different during these periods. To rule out the time issue, further research needs to be conducted on the data from the same point in time.

Another limitation is that the Indian sample size is quite larger than the others, which means that the results may have been heavily influenced by the Indian sample. Cross-country studies need comparable samples in many aspects (Brislin, Lonner \& Thorndike, 1973). Additionally, the findings of this study may not be applied to other emerging markets; that is, business environments or contexts differ between countries. For future research, samples should include other transitional economies such as Poland, Indonesia, and Mexico.

Some studies mentioned or reported that there are different features between state-owned firms and privately owned firms (e.g., Sun, Vinig \& Hosman, 2017), particularly in emerging markets (e.g., Ding, Zhang \& Zhang, 2007; Nguyen $\&$ Van Dijk, 2012). Future research needs to be conducted on the difference in factors influencing firm performance between state-owned firms and privately owned firms in emerging markets.

Furthermore, we have paid attention to labor productivity as a measure of firm performance. Labor productivity can be an important indicator for profitability, and thus labor productivity has been adopted as a measure of performance in organization research (Alaimo et al. 2009). However, organizational researchers have addressed that firm performance measures should reflect the multidimensional nature of organizational performance (Hult et al. 2008). Further studies should use diverse measures of organizational performance such as return on investment, return on assets, stock earnings, net profit, and so on.

Additionally, this study does not include country-unique features of business environments such as guanxi, which means 'relational network' in China (Luo \& Park, 2001; Peng, 2003). For example, the level of guanxi is considered as resources that have positive effects on competitive advantages in China; that is, it takes time to develop guanxi (Luo \& Park, 2001). Therefore, for better performance, it is necessary to understand which local factors of business environment influence firm productivity. Future research needs to include local factors of business that are unique to a certain emerging market.

In order to analyze the effects of explanatory variables on labor productivity, we use cross-sectional data that we collected at a certain point in time. A certain relationship suggested by this study may have reverse causality. For example, good performance leads firms to conducting external audit, which results in an external cost to them. In addition, the findings of this study show that firm age is positively associated with labor productivity, which may be related to a survival bias. Therefore, future research should use longitudinal data or include other emerging markets in order to generalize the findings of this study and to rule out survival bias.

\section{ACKNOWLEDGEMENT}

This work was supported by the Ministry of Education of the Republic of Korea and the National Research Foundation of Korea (NRF-2016S1A5A8018551). 


\section{AUTHOR BIOGRAPHIES}

Young-Hee Kang ( $1^{\text {st }}$ author) is an assistant Professor in Business Administration Department, School of Business, Keimyng University. She obtained her Ph.D from Michigan State University, East Lansing, U.S.

Kyunga Na (corresponding author) is an assistant professor in the Accounting and Taxation Department, School of Business, Keimyung University. She obtained her Ph. D from the University of Alberta, Edmonton, Canada.

Yang Sok Kim is an assistant Professor in the Department of Management Information Systems, School of Business, Keimyng University. He obtained his Ph.D from the University of Tasmania, Australia.

\section{REFERENCES}

Aidt, T. S. (2009). Corruption, institutions, and economic development. Oxford Review of Economic Policy, 25(2), $271-291$.

Alaimo, V., Fajnzylber, P., Guasch, J. L., Lopez, H. \& Oviedo, A. M. (2009). The investment climate in Latin America. In P. Fajnzylber, J. L. Guasch \& J. H. Lopez (eds.), Does the investment climate matter? Microeconomic foundations of growth in Latin America, 49-111. Washington, DC, World Bank Publications.

Alam, M. S. (1995). A theory of limits on corruption and some applications. Kyklos, 48(3), 419-435.

Amin, M. (2011). Labor productivity, firm-size and gender: The case of informal firms in Argentina and Peru (Enterprise Note No. 22). Washington, DC: World Bank Group.

Baik, Y. S., Lee, S. H. \& Lee, C. (2015). Entrepreneurial firms' choice of ownership forms. International Entrepreneurship and Management Journal, 11(3), 453-471.

Beck, T., Crivelli, J. M. \& Summerhill, M. W. (2005). State bank transformation in Brazil - Choices and consequences. Journal of Banking \& Finance, 29(8), 2223-2257.

Brislin R. W., Lonner, W. \& Thorndike, R. M. (1973). Cross-cultural research methods. New York, NY: Wiley.

Brouthers, K. D. \& Hennart. J. F. (2007). Boundaries of the firm, Insights from international entry mode research. Journal of Management, 33(3), 395-425.

Buckley, P. J., Wang, C. \& Clegg, J. (2007). The impact of foreign ownership, local ownership and industry characteristics on spillover benefits from foreign direct investment in China. International Business Review, 16(2), 142-158.

Chen, F., Hope, O. K., Li, Q. \& Wang, W. (2011). Financial reporting quality and investment efficiency of private firms in emerging markets. The Accounting Review, 86(4), 1255-1288.

Chen, Y. R., Chiou, J. R., Chou, T. K. \& Syue, M. S. (2009). Corporate governance and long-run performance of equity issues: The role of foreign ownership in Taiwan. Asia Pacific Management Review, 14(1), 27-46.

Chhibber, P. K. \& Majumdar, S. K. (1999). Foreign ownership and profitability: Property rights, control, and the performance of firms in Indian industry. The Journal of Law and Economics, 42(1), 209-238.

Claessens, S. \& Djankov, S. (1999). Ownership concentration and corporate performance in the Czech Republic. Journal of Comparative Economics, 27(3), 498-513.

Claessens, S., Djankov, S., Fan, J. P. \& Lang, L. H. (2002). Disentangling the incentive and entrenchment effects of large shareholdings. The Journal of Finance, 57(6), 2741-2771.

Coase, R. H. (1979). Payola in radio and television broadcasting. The Journal of Law and Economics 22(2), 269-328.

Collins, J. D., Uhlenbruck, H. \& Rodriguez, P. (2009). Why firms engage in corruption: A top management perspective. Journal of Business Ethics, 87(1), 89-108.

Crystal, J., Dages, B. G. \& Goldberg, L. S. (2001). Does foreign ownership contribute to sounder banks in emerging markets? The Latin American experience (Staff Report No. 137). New York, NY: Federal Reserve Bank of New York.

Davis, J. H. \& Ruhe, J. A. (2003). Perceptions of country corruption: Antecedents and outcomes. Journal of Business Ethics, 43(4), 275-288.

De Vries, G. J., Erumban, A. A., Timmer, M. P., Voskoboynikov, I. \& Wu, H. X. (2012). Deconstructing the BRICs: Structural transformation \& aggregate productivity growth. Journal of Comparative Economics, 40(2), 211-227.

DiMaggio, P. \& Powell, W. W. (1983). The iron cage revisited: Collective rationality and institutional isomorphism in organizational fields. American Sociological Review, 48(2), 147-160.

Ding, Y., Zhang, H. \& Zhang, J. (2007). Private vs. state ownership and earnings management: Evidence from Chinese listed companies. Corporate Governance: An International Review, 15(2), 223-238.

Djankov, S., Miguel, E., Qian, Y., Roland, G. \& Zhuravskaya, E. (2005). Who are Russia's entrepreneurs? Journal of the European Economic Association, 3(2-3), 587-597.

Dopuch, N. \& Simunic, D. (1982). Competition in auditing: An assessment. In University of Illinois (Ed.), Fourth Symposium on Auditing Research, 401-450. Urbana, IL: University of Illinois. 
Eunni, R. V. \& Manolova, T. S. (2012). Are the BRIC economies entrepreneur-friendly? An institutional perspective. Journal of Enterprising Culture, 20(2), 171-202.

Fan, J. P. \& Wong, T. J. (2002). Corporate ownership structure and the informativeness of accounting earnings in East Asia. Journal of Accounting and Economics, 33(3), 401-425.

Fan, J. P. \& Wong, T. J. (2005). Do external auditors perform a corporate governance role in emerging markets? Evidence from East Asia. Journal of Accounting Research, 43(1), 35-72.

Fey, C. F. \& Denison, D. R. (2003). Organizational culture and effectiveness: can American theory be applied in Russia? Organization Science, 14(6), 686-706.

Gill, I. S., Kharas, H. J. \& Bhattasali, D. (2007). An East Asian renaissance: ideas for economic growth. Washington DC: World Bank Publications.

Greenaway, D., Guariglia, A. \& Yu, Z. (2014). The more the better? Foreign ownership and corporate performance in China. The European Journal of Finance, 20(7-9), 681-702.

González, J. S. \& García-Meca, E. (2014). Does corporate governance influence earnings management in Latin American markets? Journal of Business Ethics, 121(3), 419-440.

Gonzalez, A. \& Lamanna, F. (2007). Who fears competition from informal firms? Evidence from Latin America (Policy Research Working Paper No. 4316). Washington, DC: World Bank.

He, X., Zhang, J. \& Wang, J. (2015). Market seeking orientation and performance in China: The impact of institutional environment, subsidiary ownership structure and experience. Management International Review 55(3), 389-419.

Holtbrügge, D. \& Kreppel, H. (2012). Determinants of outward foreign direct investment from BRIC countries: An explorative study. International Journal of Emerging Markets, 7(1), 4-30.

Hult, G. T. M., Ketchen, D. J., Griffith, D. A. Jr., Chabowski, B. R., Hamman, M. K., Dykes, B. J., ... \& Cavusgil, S. T. (2008). An assessment of the measurement of performance in international business research. Journal of International Business Studies, 39(6), 1064-1080.

Husted, B. W. (1999). Wealth, culture, and corruption. Journal of International Business Studies, 30(2), 339-359.

Johnson, J. L. \& O'Leary-Kelly, A. M. (2003). The effects of psychological contract breach and organizational cynicism: Not all social exchange violations are created equal. Journal of Organizational Behavior, 24(5), 627-647.

Kang, Y.-H. \& Chung, H.-Y. (2015). Small \& medium-sized enterprise (SMEs)' performance in Mexico: Relations of security cost, corruption, and informal competition to firm's performance. Asia Pacific Journal of Small Business 37(4), 57-76.

Khanna, T. \& Palepu, K. (1999). Emerging market business groups, foreign investors, and corporate governance (No. w6955). National bureau of economic research.

https://www.researchgate.net/profile/Krishna_Palepu/publication/5194930_Emerging_Market_Business_Groups_Foreig n_Investors_and_Corporate_Governance/links/555c9c5308ae9963a11207ād.pdf. Accessed January 222017.

Kraar, L. (1995). How corrupt is Asia. Fortune, 132(4), 18.

Lambsdorff, J. G. (2003). How corruption affects productivity. Kyklos, 56(4), 457-474.

LaPalombara, J. (1994). Structural and institutional aspects of corruption. Social Research, 61(2), 325-350.

Lee, S. H. \& Weng, D. H. (2013). Does bribery in the home country promote or dampen firm exports? Strategic Management Journal, 34(12), 1472-1487.

Levie, J. \& Autio, E. (2011). Regulatory burden, rule of law, and entry of strategic entrepreneurs: an international panel study. Journal of Management Studies, 48(6), 1392-1419.

Luo, Y. (2005). An organizational perspective of corruption. Management and Organization Review, 1(1), 119-154.

Luo, Y. \& Park, S. H. (2001). Strategic alignment and performance of market-seeking MNCs in China. Strategic Management Journal, 22(2), 141-155.

Martin, K. D., Cullen, J. B. \& Johnson, J. L. (2007). Deciding to bribe: A cross-level analysis of firm and home country influences on bribery activity. Academy of Management Journal, 50(6), 1401-1422.

Morck, R., Yeung, B. \& Yu, W. (2000). The information content of stock markets: Why do emerging markets have synchronous stock price movements? Journal of financial economics, 58(1), 215-260.

Nguyen, T. T. \& Van Dijk, M. A. (2012). Corruption, growth, and governance: Private vs. state-owned firms in Vietnam. Journal of Banking \& Finance, 36(11), 2935-2948.

Peng, M. W. (2003). Institutional transitions and strategic choices. Academy of Management Review, 28(2), $275-296$.

Puffer, S. M., McCarthy, D. J. \& Boisot, M. (2010). Entrepreneurship in Russia and China: The impact of formal institutional voids. Entrepreneurship Theory and Practice, 34(3), 441-467.

Rodriguez, P., Uhlenbruck, K. \& Eden, L. (2005). Government corruption and the entry strategies of multinationals. Academy of Management Review, 30(2), 383-396.

Ruiz, M., Pérez, J., Bona, C. \& Santana, D. (2009). Calidad del resultado y propiedad institucional [Quality of the result and institutional property] (Working Paper). Las Palmas, Spain: Universidad de las Palmas de Gran Canaria.

Samudhram, A., Stewart, E., Wickramanayake, J. \& Sinnakkannu, J. (2014). Value relevance of human capital based disclosures: Moderating effects of labor productivity, investor sentiment, analyst coverage and audit quality. Advances in Accounting, 30(2), 338-353.

Sanchez, J. I., Gomez, C. \& Wated, G. (2008). A value-based framework for understanding managerial tolerance of bribery in Latin America. Journal of Business Ethics, 83(2), 341-352. 
Schneider, F. \& Enste, D. (2000). Shadow economies around the world size, causes, and consequences. Journal of Economic Literature, 38(1), 77-114.

Spencer, J. \& Gomez, C. (2011). MNEs and corruption: The impact of national institutions and subsidiary strategy. Strategic Management Journal, 32(3), 280-300.

Sun, Z., Vinig, T. \& Hosman, T. D. (2017). The financing of Chinese outbound mergers and acquisitions: Is there a distortion between state-owned enterprises and privately owned enterprises?. Research in International Business and Finance, 39 , 377-388.

Transparency International. (2011). Bribe payers index 2011. http://www.transparency.org/bpi2011

United Nations, Department of Economic and Social Affairs (2015). World population prospects: The 2015 revision: Key findings \& advance tables (ESA/P/WP, 241). New York, NY: Author. https://esa.un.org/unpd/wpp/Publications/

Wei, S.-J. (2000). How taxing is corruption on international business? The Review of Economics and Statistics, 82(4), 1-12.

$\mathrm{Wu}, \mathrm{X}$. (2005). Political institutions and corporate governance reforms in Southeast Asia. Reforming Corporate Governance in Southeast Asia: Economics, Politics and Regulation, 16-37.

Wu, X. (2009). Determinants of bribery in Asian firms: Evidence from the world business environment survey. Journal of Business Ethics, 87(1), 75-88. 


\section{NOTES}

